\title{
WYKORZYSTANIE ŚWIATŁA SPOLARYZOWANEGO W LECZENIU OPARZEŃ - OPIS PRZYPADKU
}

\author{
USE OF POLARIZED LIGHT TO TREAT BURNS - CASE STUDY \\ Martyna Dębska-Maik \\ mgr, doktorantka, Wydział Lekarski i Nauk o Zdrowiu, Uniwersytet Jana Kochanowskiego w Kielcach \\ DOI: https://doi.org/10.20883/ppnoz.2019.35
}

\section{STRESZCZENIE}

Terapia świattem spolaryzowanym ma wiele zastosowań. Przede wszystkim powoduje poprawienie mikrocyrkulacji, przyśpiesza gojenie się ran, wspiera system obronny organizmu, pobudza procesy regeneracyjne, zmniejsza ból bądź eliminuje go. Korzystne skutki, jakie niesie ze sobą stosowanie światła spolaryzowanego, sprawiają, że coraz więcej terapeutów wykorzystuje omawianą metodę.

Celem niniejzzego artykułu było przedstawienie efektów leczenia 24-letniej pacjentki z oparzeniem przy zastosowaniu światła spolaryzowanego.

Pacjentka została objęta leczeniem z powodu oparzenia II stopnia w okolicy nadgarstka. Oparzenie objawiało się pęcherzem, zwiększoną ciepłotą, częściową martwicą naskórka, obrzękiem (4mm). U pacjentki zastosowano terapię światłem spolaryzowanym Bioptron. Zabiegi przeprowadzono w dwóch seriach, każda po 10 naświetleń. Ostatecznie oparzenie zagoiło się. Proces leczenia trwał 10 dni zabiegowych.

Słowa kluczowe: oparzenie, zdrowie, światło spolaryzowane.

ABSTRACT

Polarized light therapy has many uses. First of all, it improves microcirculation, accelerates healing of wounds, supports the body's defense system, stimulates regenerative processes, reduces pain or eliminates it. The beneficial effects of using polarized light make more and more therapists use this method. The aim of this article was to present the effects of treatment of a 24-year-old patient with burns using polarized light.

The patient was treated for second degree burns near the wrist. Burns were blistered, increased warmth, partial epidermal necrolysis, edema (4mm). Bioptron polarized light therapy was used in the patient. The treatments were performed in two series, each with 10 exposures. Eventually, burns disappeared. The treatment process lasted 10 days.

Keywords: burn, health, polarized light

\section{Wstęp}

Światłolecznictwo jest elementem medycyny fizykalnej. Badania wykazują, że człowiek zmienia energię elektromagnetyczną światła w energię elektrochemiczną, która rozpoczyna łańcuch wewnątrzkomórkowych reakcji biochemicznych, pobudzając przemianę materii oraz aktywność układu immunologicznego [1]. Dzięki temu pobudzony zostaje proces regeneracji tkanek. Pewna część światła słonecznego ulega polaryzacji i to właśnie wspomniany fragment światła odpowiada za właściwości lecznicze [2-3].

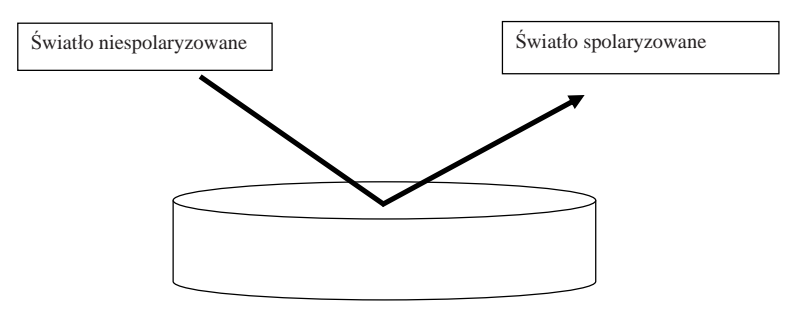

Rycina 1. Polaryzacja światła Źródło: Opracowanie własne
Lampa Bioptron zostaje wykorzystywana w celach leczniczych. Posiada ona cechy biostymulujące [4-6]. Światło powoduje komórkową reakcję łańcuchową, jak również drugorzędne odruchy. Korzysta z połączenia światła widzialnego ispolaryzowanego (więcej niż 95\%), które obejmuje widoczny składnik spektrum światła słonecznego oraz bliższej podczerwieni (długość fali $480 \mathrm{~nm}-3400 \mathrm{~nm}$ ) [7]. Fale poruszają się w płaszczyznach równoległych w stosunku do świecenia, w przeciwieństwie od fal słonecznego światła, które roznoszą się w różne kierunki [7]. Światło Bioptron nie posiada szkodliwego promieniowania dla zdrowia człowieka. "Lampa Bioptron emituje światło niespójne, przesunięte w fazie. Energia fali świetlnej Bioptronu jest w każdej jednostce czasu jednakowa" [7]. Światło Bioptron mieści się wyżej niż ultrafioletowa część spektrum i posiada niską gęstość energii [7-9]. Terapia Bioptron wykorzystuje światło spolaryzowane, polichromatyczne, niekoherentne oraz niskoenergetyczne [1-9]. 
Terapia światłem spolaryzowanym ma wiele zastosowań. Przede wszystkim powoduje poprawienie mikrocyrkulacji, przyśpiesza gojenie się ran, wspiera system obronny organizmu, pobudza procesy regeneracyjne, zmniejsza ból bądź eliminuje go, zmniejsza opuchliznę, poprawia odżywienie tkanek, poprawia samopoczucie, polepsza krążenie w małych naczyniach krwionośnych (Tabela 1) [10].

Tabela 1. Zastosowanie terapii światłem Bioptron

\begin{tabular}{|l|l|}
\hline \multicolumn{1}{|c|}{ Zakres } & \multicolumn{1}{|c}{ Przykłady } \\
Gojenie ran & Leczenie ran pourazowych \\
Przeszczepy & Oparzenia \\
Reumatologia & Leczenie ran pooperacyjnych \\
Odleżyny & Żylne owrzodzenia podudzi \\
Zmniejszenie dolegliwości & Zwyrodnienie stawów \\
bólowych & Przewlekle zapalenie stawów \\
Choroba zwyrodnieniowa \\
stawów \\
Kręgosłup \\
Kończyny \\
Zespół cieśni nadgarstka \\
Blizny \\
Układ mięśniowo-szkieletowy \\
Urazy ścięgien i więzadeł, \\
tkanek miękkich \\
Skurcze mięśni \\
Stłuczenia \\
Skręcenia \\
Zwichnięcia \\
Zapalenia ścięgien \\
Naderwania więzadeł i mięśni \\
Łuszczyca \\
Trądzik \\
Atopowe zapalenie skóry \\
Opryszczka, Półpasiec \\
Powierzchniowe infekcje \\
bakteryjne \\
Egzema endogenna \\
Dolegliwości skórne \\
Zaburzenia układu mięśniowo- \\
-szkieletowego, nerwowego \\
Alergiczne choroby dróg \\
oddechowych \\
Infekcje górnych dróg \\
oddechowych
\end{tabular}

Źródło: Opracowanie własne
Oparzenia oraz sparzenia termiczne są to efekty miejscowego działania na skórę człowieka temperatury powyżej $50^{\circ} \mathrm{C}$ [11]. Oparzenia powodują zwiększenie ciepłoty skóry, ból, rumień, denaturacje białek [11]. Oparzenia można podzielić, ze względu na głębokość uszkodzenia, na trzy stopnie [11].

Celem niniejszego artykułu było przedstawienie efektów leczenia przy zastosowaniu światła spolaryzowanego wobec 24-letniej pacjentki z oparzeniem.

\section{Opis przypadku}

Pacjentka, w listopadzie 2016 r., została objęta leczeniem z powodu oparzenia II stopnia w okolicy nadgarstka. Oparzenie objawiało się pęcherzem, zwiększoną ciepłotą, częściową martwicą naskórka, obrzękiem (4 mm). U kobiety stwierdzono przeczulicę na dotyk w okolicy rany. Przed rozpoczęciem leczenia kobieta wypełniła skrócony kwestionariusz oceny bólu w dziesięciopunktowej skali wzrokowo-analogowej VAS. Uzyskany wynik (5 pkt.) odpowiadał przeciętnemu nasilaniu dolegliwości bólowych. Rana miała wielkość $15 \mathrm{~mm}$ na $24 \mathrm{~mm}$.

U pacjentki zastosowano terapię światłem spolaryzowanym Bioptron o długości fali pomiędzy $480 \mathrm{~nm}$ a $3400 \mathrm{~nm}$. Gęstość mocy światła określano na poziomie $40 \mathrm{~mW} / \mathrm{cm}^{2}$ przy odległości od skóry ok $10 \mathrm{~cm}$, gęstość energetyczna to średnio $2,4 \mathrm{~J} / \mathrm{cm}^{2}$. Czas trwania naświetlenia wynosił $10 \mathrm{~min}$. Zabieg był wykonywany na okolicę rany, metodą bezkontaktową, w odległości ok $10 \mathrm{~cm}$ od powierzchni oparzenia. Po każdym naświetlaniu ochronnie aplikowano opatrunek.

Zabiegi przeprowadzono $w$ dwóch seriach, każda po 10 naświetleń (2 razy w ciągu dnia') z przerwą sobotnioniedzielną. W czasie przebiegu pierwszej serii leczniczej kobieta zgłosiła zmniejszenie dolegliwości bólowych, jednak po 10 naświetleniu (5 dzień zabiegowy) pacjentka skarżyła się na wzmożone swędzenie okolicy oparzenia. Stan po zakończeniu pierwszej sesji naświetleń można zobaczyć na rycinie 4.

Po zakończeniu leczenia pacjentka zawiadomiła o kompletnym ustąpieniu bólu, według skali VAS: 0 . W trakcie naświetleń obserwowano ziarninę oraz naskórkowanie o intensywnym nasileniu. Ostatecznie oparzenie zagoiło się, zaczerwienienie zmniejszyło się. Stan miejscowy oparzenia po zakończeniu cyklu leczenia (łącznie 20 naświetleń) przedstawiono na rycinie $\mathbf{6}$. Proces leczenia trwał 10 dni zabiegowych. 


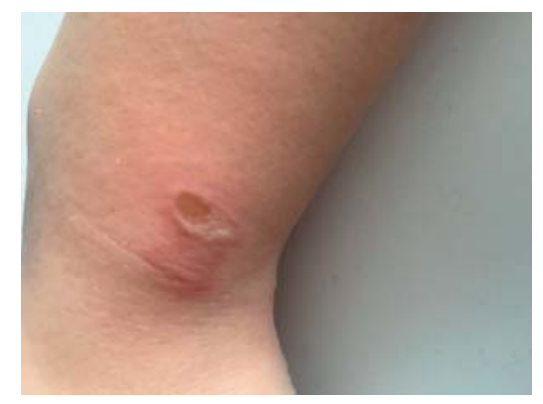

Rycina 2. Oparzenie - stan przed naświetlaniem światłem spolaryzowanym

Źródło: Opracowanie własne

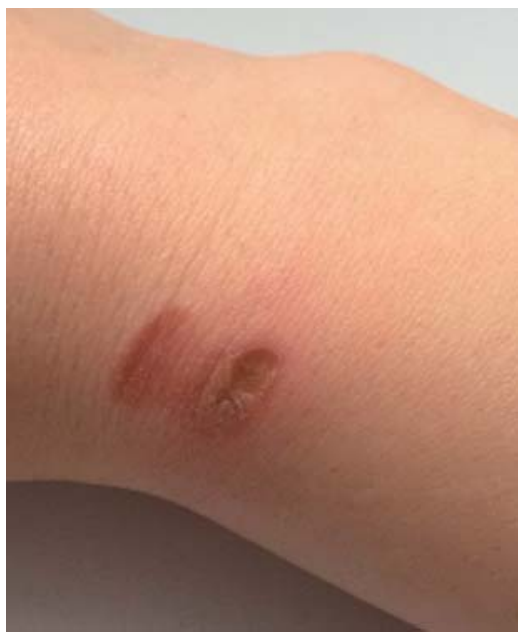

Rycina 3. Oparzenie w trakcie naświetlania podczas I sesji zabiegowej Źródło: Opracowanie własne

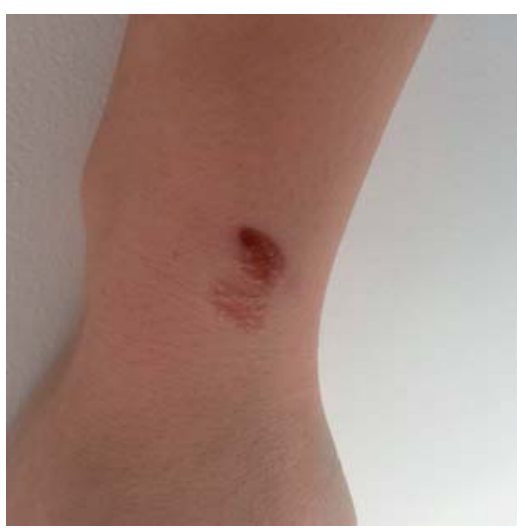

Rycina 4. Oparzenie po I sesji zabiegowej

Źródło: Opracowanie własne

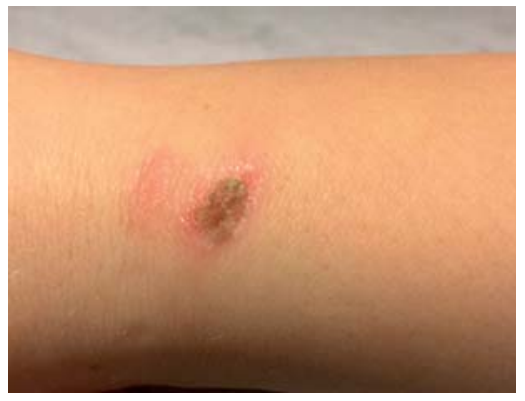

Rycina 5. Oparzenie w trakcie naświetlania podczas II sesji zabiegowej Źródło: Opracowanie własne

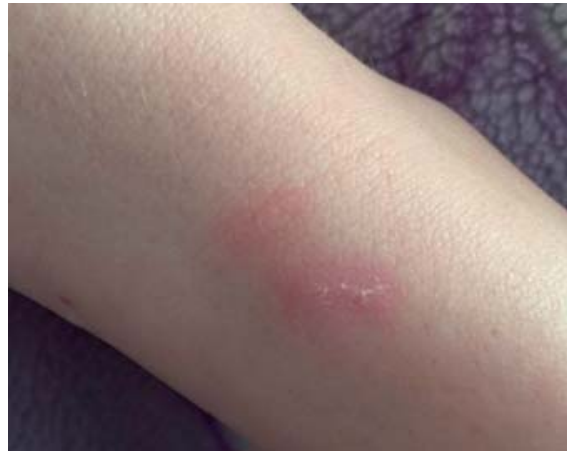

Rycina 6. Stan miejscowy po zakończeniu cyklu naświetleń Źródło: Opracowanie własne

\section{Dyskusja}

Światło spolaryzowane stosuje się $\mathrm{w}$ fizjoterapii. W prezentowanej pracy autorka omówiła opis przypadku zastosowania światła spolaryzowanego Bioptron w leczeniu oparzenia.

Zdaniem Janosik E. światło spolaryzowane można wykorzystywać w leczeniu oparzeń, odleżyn czy różnego rodzaju ran [13]. Lampa BIOPTRON posiada właściwości niekoherentne oraz niskoenergetyczne [1-13]. „Niekoherentność wiązki sprawia, że natężenia światła nie sumują się, a zatem światło dostarczane jest do tkanki ze stałą, niewielką intensywnością" [13].

Oparzenia II stopnia objawiają się pęcherzykami i częściową martwicą i dotyczą skóry [11]. Oparzenia te są zazwyczaj bolesne i można było to również zaobserwować u pacjentki.

Światło spolaryzowane pomaga w leczeniu oparzeń. Korzystne efekty można było zaobserwować w opisywanym przypadku. Juz po 10 dniu zabiegowym rana całkowicie się zagoiła.

\section{Podsumowanie}

Korzystne skutki, jakie niesie ze sobą stosowanie światła spolaryzowanego, sprawiają, że coraz więcej terapeutów wykorzystuje omawianą metodę. Ma ona szerokie zastosowanie w medycynie. W przekonaniu autorki terapia z użyciem światła spolaryzowanego jest przydatnym sposobem pomagającym leczenie chorych z oparzeniami.

\section{Oświadczenia}

Oświadczenie dotyczące konfliktu interesów Autorzy deklarują brak konfliktu interesów.

\section{Źródła finansowania}

Autorzy deklarują brak źródeł finansowania. 


\section{Piśmiennictwo}

1. Pasek J, Cieślar G, Stanek A, Pasek T, Sieroń A. Światło spolaryzowane $w$ leczeniu owrzodzenia goleni o nieznanej etiologii - opis przypadku. Przegląd Flebologiczny 2010; 18: 57-60.

2. Pasek J, Cieślar G, Pasek T, Sieroń A. Leczenie światłem spolaryzowanym - nowe możliwości światłolecznictwa? Balneologia Polska 2008; 50:93-99.

3. Sieroń A, Pasek J, Mucha R. Światło niskoenergetyczne w medycynie i rehabilitacji. Rehabilitacja Praktyczna 2007; 2:25-27.

4. Karu T. Molecular mechanism of therapeutic effect of lowintensity irradiation. Laser Life Sci 1988; 2: 63-71.

5. Karu T. Primary and secondary mechanisms of action of visible to near-IR radiation on cells. J Photochem Photobiol 1999; 49: 1-17.

6. Smith KC. The photobiological basis of low-level laser radiation therapy. Laser Therapy 1991; 3: 19-24.

7. Helbin J, Kolarzyk E. Czynniki fizykalne wykorzystywane w metodach lecznictwa uzdrowiskowego. Problemy Higieny i Epidemiologii 2006; 87: 166-171.

8. Zembaty A. Kinezyterapia T. 1. Zarys podstaw teoretycznych i diagnostyka kinezyterapii. Kasper, Kraków 2002.

9. Mika A, Kasprzak W. Fizykoterapia, Wydawnictwo Lekarskie PZWL, Warszawa 2001
10. Skoracka J, Torlińska T, Hubert J, Witkowska A. Wpływ światła spolaryzowanego liniowo o różnej długości fali na czynność jednostek ruchowych mięśnia żwacza. Nowiny Lekarskie 2007; 76: 114-120.

11. Kwieciński A. Farmakologia w leczeniu oparzeń. Farmaceutyczny Przegląd Naukowy 2007; 3: 16-19.

12. Janosik E. Światło spolaryzowane i jego zastosowanie w medycynie. Prace Instytutu Elektrotechniki 2006; 228: 317-325.

13. Kużdżał A, Walaszek R. Zastosowanie widzialnego, polichromatycznego światła spolaryzowanego (VIP Light) w rehabilitacji. Część IV: Przydatność światła VIP w leczeniu trudno gojących się ran. Fizjoterapia 2004; 2: 55-63.

Zaakceptowano do edycji: 20.08 .19

Zaakceptowano do publikacji: 26.09.19

\section{Adres do korespondencji:}

Martyna Dębska-Maik

Zagórze 4

96-200 Rawa Mazowiecka

tel. 603966928

e-mail: info.bettersimply@gmail.com 